\title{
GOVERNAMENTALIDADE E ANARQUEOLOGIA EM MICHEL FOUCAULT
}

\section{Nildo Avelino}

\section{Introdução}

A partir de 1980 Michel Foucault introduz uma nova problematização nos estudos sobre as relações de poder pela qual renovou consideravelmente seu "método" de análise: trata-se da anarqueologia dos saberes, que consiste no deslocamento que levou do eixo de análise "poder-saber" para o "governo dos homens pela manifestação da verdade sob a forma da subjetividade" (Foucault, 2010, p. 64). Com a anarqueologia, Foucault conferiu um grau de complexidade extraordinário às suas pesquisas, resultando, anos mais tarde, na formulação do tema da estética da existência.

* Agradeço a Ana Novais e Geraldo Escudero pelo trabalho de revisão, e a Francisco Ripó pela leitura e comentários.
Além disso, a anarqueologia prolonga e reelabora as análises iniciadas por Michel Foucault em 1978 acerca da governamentalidade. Foucault passa a investigar as práticas de governo no plano discursivo e performático, tornando evidente os processos históricos pelos quais verdade e subjetividade foram indexadas para a produção da obediência no exercício do governo. A obrachave para apreender o tema da anarqueologia é o curso intitulado Du gouvernement des vivants, proferido por Foucault no Collège de France em 1980.

Neste artigo, abordo essas duas noções procurando compreender, nos deslocamentos que elas provocam, o percurso empreendido pelo pensamento foucaultiano que conduziu ao período ainda pouco explorado pelas ciências sociais no Brasil, o chamado "último Foucault". 


\section{Governamentalidade: da guerra ao governo}

Segundo Daniel Defert, em dezembro de 1972 Foucault empreende uma análise das relações de poder a partir da "mais indigna das guerras: nem Hobbes, nem Clausewitz, nem luta de classes, mas a guerra civil" (2001, p. 57). O curso intitulado La société punitive, proferido no Collège de France em 1973, descreve essa análise. Foucault analisa o domínio histórico das táticas punitivas empregadas nas sociedades ocidentais contra os indivíduos que infringiram suas leis, suas regras, o exercício de seu poder. Propõe definir, a partir de quatro grandes táticas punitivas (exclusão, compensação, marca e, particularmente, clausura), quais relaçôes de poder foram efetivamente colocadas em funcionamento. Nesse sentido, as táticas punitivas funcionam na análise não como reveladores de uma ideologia, mas como analisadores das relações de poder, e Foucault acrescenta que:

[...] se é verdade que o sistema das táticas penais pode ser visto como analisador das relaçôes de poder, o elemento que será considerado central é o elemento da luta política em torno do poder e contra ele; é o jogo dos conflitos, de lutas que existem entre o poder tal como ele é exercido numa sociedade e os indivíduos ou grupos que buscam, de uma maneira ou de outra, escapar desse poder, contestá-lo localmente ou globalmente, contradizendo suas ordens e suas regras. [...] É, portanto, a noção de 'guerra civil' que deve ser colocada no coração de todas essas análises das penalidades (1973, fl. 16).

A noção de guerra civil é tomada como uma espécie de matriz geral das lutas em torno, a propósito e contra o poder, da matriz para uma análise do jogo entre a luta permanente e as diversas táticas de poder. Segundo Foucault, seja em Hobbes seja em Rousseau, a guerra civil jamais foi considerada uma realidade positiva para servir de base analítica. Do ponto de vista político e filosófico, ela foi quase sempre um conceito mal elaborado, considerada anterior ao pacto social (particularmente em Hobbes) e, portanto, assimilada à guerra de todos con- tra todos, isto é, ao estado pré-político. Foucault, ao contrário, procura mostrar que a guerra civil:

[...] habita, atravessa, anima, investe o poder em toda parte. Encontram-se precisamente estes sinais sob a forma da vigilância, da ameaça, do monopólio da força armada, numa palavra, de todos os instrumentos de coerção que o poder efetivamente estabelecido utiliza no seu exercício. $\mathrm{O}$ exercício cotidiano do poder deve ser considerado uma guerra civil; exercer o poder é, de alguma maneira, conduzir à guerra civil, e todos esses instrumentos, essas táticas de que falei, essas alianças, devem ser analisados em termos de guerra civil (Idem, fls. 32-33).

Essas passagens mostram claramente a ligação de Foucault ao tipo de análise realizada na História da loucura, em que descreveu o surgimento na Europa de "uma categoria da ordem clássica" conhecida como internamento e que levou $1 \%$ da população parisiense para o interior do Hospital Geral poucos anos após sua fundação, atingindo bruscamente "seu limiar de manifestação na segunda metade do século XVII" sob a forma da exclusão pelo internamento como fato maciço (1999a, p. 55). Após História da loucura, essa mesma análise foi retomada em $A$ ordem do discurso, aula inaugural no Collège de France pronunciada em 1970, na qual Foucault descreveu os procedimentos de exclusão e interdição que durante séculos atravessaram a vontade de saber no Ocidente (1999b, p. 14). Portanto, é ainda retomando o fio dessas análises que o curso de 1973 irá estabelecer para instrumento de estudo não a guerra de todos contra todos, mas a guerra social, a "guerra de ricos contra pobres, de proprietários contra os que nada possuem, de patrôes contra proletários" (1973, fl. 18 ), e isso para compreender o aparecimento e o funcionamento, no século XIX, da estratégia penal do enclausuramento.

Entretanto, essa análise foi em seguida considerada inadequada por Foucault. Após a aparição do primeiro volume da História da sexualidade, em uma entrevista de janeiro de 1977, o autor reconheceu ter aceito, em seus escritos anteriores, a concepção tradicional do poder como aquilo que dita 
a lei, que interdita, que diz não. Concepção essa que, segundo ele, condizia com o período clássico no qual "o poder se exerceu sobre a loucura, sem dúvida, sob a forma maior da exclusão" (2001b, p. 229), mas que se mostrava insuficiente para descrever o exercício do poder na atualidade. Afirmação, por sua vez, confirmada por Pasquale Pasquino, seu colaborador no Collège de France, ao observar que, a partir da segunda metade dos anos de 1970, o discurso sobre guerra e dominação, utilizado por Foucault para descrever as práticas disciplinares, havia provocado um impasse que

[...] conduziu a uma crítica extremista do poder - visto segundo um modelo repressi$v o$ - pela esquerda [...]. Uma análise fechada das disciplinas oposta às teses marxistas da exploração econômica como princípio para compreender os mecanismos do poder não era suficiente, e reclamou a investigação de problemas globais de regulação e ordem na sociedade, bem como as modalidades para a conceitualização deste problema. Daí a questão do governo - termo que substituiu gradualmente a noção de "poder", considerada por Foucault uma palavra muito ambígua (Pasquino, 1993, p. 79).

Resulta equivocado, portanto, atribuir a inversão do aforismo de Clausewitz, que afirmou a política como guerra por outros meios, ao curso $E m$ defesa da sociedade de 1976. Essa inversão já tinha sido feita no curso de 1973, cuja análise da guerra civil levou Foucault a afirmar com ênfase "que o poder não é o que suprime a guerra civil, mas o que a reconduz e lhe dá continuidade; e, se é verdade que a guerra exterior é o prolongamento da política, é preciso dizer, reciprocamente, que a política é a continuação da guerra civil" (1973, fl. 33). Ao contrário do que se afirma frequentemente, o curso de 1976 apresenta o início de uma longa e seminal problematização da análise que tomou a guerra como elemento analisador da política.

É verdade que no curso de 1976 Foucault (1999c, p. 26) introduz em sua analítica do poder a chamada "hipótese Nietzsche", que consiste em considerar a guerra, a luta e o enfrentamen- to como princípio e motor do poder político em nossas sociedades. Mas, agora, o nível analítico se torna bem mais elaborado. Ao perguntar se "o poder, pura e simplesmente, é uma guerra continuada por meios que não as armas ou as batalhas?" e se é preciso ou não "entender que a sociedade em sua estrutura política é organizada de maneira que alguns possam se defender contra os outros, ou defender sua dominação contra a revolta dos outros, ou simplesmente ainda, defender sua vitória e perenizá-la na sujeição?”, Foucault hesita uma resposta afirmativa. Propóe, ao contrário, certo número de precauções de método. Insiste, por exemplo, em não tomar a dominação que o poder pretende perenizar como "fato maciço de 'uma' dominação global de uns sobre os outros, ou de um grupo sobre o outro", mas percebê-la como "múltiplas formas de dominação que podem se exercer no interior da sociedade". A dominação não deve ser compreendida como "o rei em sua posição central, mas os súditos em suas relaçōes recíprocas"; não é "a soberania em seu edifício único" que a sustenta, mas são, sobretudo, "as múltiplas sujeiçōes que ocorreram e funcionam no interior do corpo social" (Idem, pp. 31-32).

Era necessário não reduzir as relaçōes de poder às formas de dominação. E o problema da noção de guerra é que ela reforçava a ambiguidade da noção de poder. É preciso, diz Foucault nessa segunda metade dos anos de 1970, evitar os "esquemas prontos" que, ao ouvir a palavra poder, induzem pensar "numa estrutura política, num governo, numa classe social, no mestre diante do escravo etc." (Foucault, 2001b, p. 1538). Essa ambiguidade fazia os estados de dominação figurarem como aquilo "que ordinariamente chama-se o poder" (Idem, p. 1547). Daí a necessidade de introduzir a distinção entre poder e dominação, entre política e guerra. Isso é feito a partir do primeiro volume da História da sexualidade. Ao questionar se "seria preciso inverter a fórmula e dizer que a política é a guerra prolongada por outros meios?" (1993, p. 89), Foucault responde que seria necessário, ao contrário, distinguir guerra e política, na medida em que esses dois termos constituem efetivamente dois tipos de estratégias, diferentes uma da outra, para a codificação das relaçôes de força. 
Trata-se, em suma, de orientar, para uma concepção do poder que substitua [...] o privilégio da soberania pela análise de um campo múltiplo e móvel de correlações de força, [em que] se produzam efeitos globais, mas nunca totalmente estáveis, de dominação. O modelo estratégico, [em vez] do modelo do direito. E isso, não por escolha especulativa ou preferência teórica; mas porque é efetivamente um dos traços fundamentais das sociedades ocidentais o fato de as correlações de força que, por muito tempo tinham encontrado sua principal forma de expressão na guerra, em todas as formas de guerra, terem-se investido, pouco a pouco, na ordem do poder político (Idem, p. 97).

Assimilar guerra e política arriscava uma simplificação dos mecanismos complexos das relaçōes de poder da atualidade, reduzindo todas as correlaçôes de força que lhe são intrínsecas às peripécias de uma guerra.

Parece-me que a pura afirmação de uma 'luta' não pode servir de explicação primeira e última para a análise das relaçóes de poder. Esse tema da luta não se torna operatório a não ser que se estabeleça concretamente, e a propósito de cada caso, quem está em luta, a propósito do que, como se desenrola a luta, em qual lugar, com quais instrumentos e segundo qual racionalidade (Foucault, 2001b, p. 206).

A política entendida como guerra induzia pensar a lei em termos de sobrevivência arcaica da soberania, as instituiçóes jurídico-políticas como que atravessadas por um modelo da guerra e a disciplina como um tipo de proeminência longínqua da soberania na modernidade. Evocava as imagens de uma violência primitiva que dobra, rompe, destrói; que "fecha todas as possibilidades; que não tem outro polo que não o da passividade; e que, ao encontrar uma resistência, não tem outra escolha a não ser reduzi-la" (Idem, p. 1055). Em suma, trazia novamente para a análise o desgastado pressuposto da hipótese repressiva: aquele de "um poder que só teria a potência do 'não', apto apenas a colocar limites" e a existir somente no negativo e como antienergia; poder cuja eficácia implica o paradoxo de "nada poder, a não ser levar aquele que sujeita a não fazer senão o que lhe permite" (Foucault, 1993, p. 83).

Para o autor, a problemática das relações de poder torna-se bem mais complexa. Em vez de pensar a política contendo velhos arcaísmos de tipo guerreiro, seria preciso pensar qual poderia ser o lugar da lei, da dominação disciplinar e da guerra no interior das formas governamentais do presente. Nesse sentido, como observou Dean,

Foucault empenhou-se em considerar a maneira pela qual a arte de governar transformou e reconstituiu os aparatos estatais jurídicos e administrativos do século XX. [...] Nem a imagem da soberania, nem a linguagem da dominação e da repressão, podem dar conta da emergência da autoridade governamental e do lugar da lei e das instituiçôes legais no seu interior (1999, p. 26).

Contudo, seria igualmente impreciso tomar o curso de 1976 como o simples abandono ou substituição da concepção do poder como guerra. Foucault interrogou os pressupostos e as consequências históricas da recorrência do modelo da guerra como base analítica das relaçōes de poder, o que não aproxima sua análise da noção de governança. Se as relaçōes de poder não se assimilam simplesmente às formas de guerra e dominação é porque estas estão configuradas em termos de relaçôes agônicas que são "ao mesmo tempo de incitação recíproca e de luta, [...] de provocação permanente" (Foucault, 2001b, p. 1057). Mas são relaçôes agônicas que fazem duas estratégias distintas, guerra e poder político, estarem sempre "prontas a se transformarem uma na outra." (Foucault, 1993, p. 89) Como observou Dean, para Foucault, as relações de poder se tornam políticas "quando ultrapassam um certo limiar de intensidade, e quando a luta não está apenas no corte e na perfuração da palavra, mas sobre os meios pelos quais a decisão para lutar pode ser forçosamente imposta, e quando os riscos recaem sobre matérias de vida e de morte" (2007, p. 11). No tipo de sociedade como a nossa, a intensidade desse agonismo encontra uma gravidade na ordem do governo: é o governo, e a resistência que ele provoca, que torna altamente politizável a ubiquidade das relações de poder. 
Assim, melhor do que supor o abandono do tema da guerra, seria compreender os efeitos de conjunto na analítica do poder de Foucault que o deslocamento provoca. Como notou Senellart, ao deslocar "o discurso da batalha utilizado desde o começo dos anos de 1970, é o conceito de governo que marca o primeiro movimento, acentuado em 1980, que leva da analítica do poder à ética do sujeito" (2004, p. 382). Desse modo, ao assinalar a distinção entre política e guerra, Foucault introduz, a partir de 1978, no curso Sécurité, territoire, population, a problemática do governo. É importante perceber o que está em jogo na introdução dessa problemática. Pierre Lascoumes sugeriu situá-la no contexto dos anos de 1970, no qual se demoliam os grandes mitos liberadores, sobretudo do comunismo, que sustentavam em relação ao Estado uma crítica globalizante. "Tirano mascarado ou liberador potencial, a noção de Estado suscitou, desde o século XVIII, muitas teorias unificadoras, frequentemente sob a forma de utopias positivas (propondo a edificação de um modelo social) ou críticas (denunciando um modelo de dominação)" (2004, p. 169).

Creio que, além disso, é importante considerar a problematização da política como guerra no interior da própria prática intelectual de Michel Foucault, e que pode ser descrita em três momentos: no final dos anos de 1960 como arqueologia, no começo dos anos de 1970 como genealogia e, por fim, como anarqueologia a partir dos anos de 1980.

Longe de supor a ideia de sucessão, essas três noçôes que, grosso modo, definem a possibilidade de uma "metodologia" foucaultiana complementam-se e implicam-se entre si. Uma descrição arqueológica recusa a análise em termos de ideologia e propóe uma abordagem do saber a partir da materialidade do discurso, ou a partir do que Foucault chamou de regularidades discursivas.

"Regularidade [...] designa [...] o conjunto das condiçōes nas quais se exerce a função enunciativa que assegura e define sua existência. A regularidade [...] especifica um campo efetivo de aparecimento. Todo enunciado é portador de uma certa regularidade e não pode dela ser dissociado" (Foucault, 2002, p. 165).
As regularidades do discurso não compreendem vastas unidades descritivas tais como a história global, geral, de uma época, cultura ou sociedade; e ao recusar as totalizaçôes e enfatizar as relações entre as séries de acontecimentos, a arqueologia tornou possível o procedimento genealógico para "a constituição de um saber histórico das lutas". Segundo Foucault, para "fazer a história de certos tipos de discursos, portadores de saber, era preciso levar em conta relações de poder que existem na sociedade [em que] esse discurso funciona" (Foucault, 2001a, p. 1277). Assim, a genealogia, retomada da obra de Nietzsche, restabeleceria os diversos sistemas de sujeição, o jogo fortuito das dominações, no decorrer de uma história efetiva que faria emergir o acontecimento ou as relaçóes de força que incessantemente se invertem e se revertem no acaso da luta.

Com o termo história efetiva Nietzsche (2001, p. 59) afirmou a ausência de história para tudo o que deu colorido à existência, sendo preciso fazer a história da inveja, da crueldade, da cupidez, da piedade, do amor, do castigo, do trabalho e do repouso. E neste vasto trabalho genealógico, Nietzsche definiu a história efetiva como "a coisa documentada, o efetivamente constatável, o realmente havido" (1988, p. 15). Com isso, seria possível perceber como "todos os fins, todas as utilidades são apenas indícios de que uma vontade de poder se assenhoreou de algo menos poderoso e lhe imprimiu o sentido de uma função" (Idem, p. 81). Para Nietzsche, a história efetiva deveria indicar que o desenvolvimento de uma coisa é menos da ordem do progresso do que de uma sucessão de processos de subjugação; daí sua ênfase no que considerou "ponto de vista capital do método histórico", a saber, "a teoria de uma vontade de poder operante em todo acontecer" (Idem, p. 82).

Retomando o sentido histórico de Nietzsche, definido como "a capacidade de perceber rapidamente a hierarquia de valoraçôes" (2002, p. 128), Foucault afirmou que a genealogia consiste em uma "história das morais, dos ideais, dos conceitos metafísicos, história do conceito de liberdade ou da vida ascética, como emergências de interpretaçōes diferentes" (2001a, p. 1015). Na história efetiva nada é fixo, nada é constante, nem mesmo o corpo. Dessa forma, quando se adota o prisma 
reflexivo da história efetiva, não é mais possível definir o poder em termos de substância ou atributo. Ao contrário, é preciso descrever seu exercício como um "conjunto de mecanismos e de procedimentos que têm por papel, função e tema, mesmo sem êxito, precisamente o de assegurar o poder" (Foucault, 2004a, p. 4).

Uma teoria do poder que repousasse sobre a análise global de uma sociedade, ou de suas transformações econômicas e estruturais, seria insuficiente. Nesse sentido, na sua analítica do poder, Foucault tomou a decisão teórico-metodológica de não partir de noções como soberania, povo, súditos, Estado, sociedade civil, mas considerar as práticas governamentais como dadas, refletidas e racionalizadas, para compreender a maneira pela qual essas mesmas noções tidas como universais pela análise sociológica e histórica foram constituídas. Com isso, o sentido histórico escapa da metafísica.

Parto da decisão, teórica e metodológica, que consiste em dizer: suponhamos que os universais não existam, nesse momento eu coloco esta questão à história e aos historiadores: como é possível escrever a história sem admitir a priori a existência de qualquer coisa como o Estado, a sociedade, o soberano, os súditos? [...] Não interrogar os universais utilizando-se como método crítico a história, mas partir da decisão da inexistência dos universais para perguntar qual história é possível (Foucault, 2004b, p. 5).

Dessa forma, o curso de 1978, no qual Foucault introduz a problemática do governo, deixa claro que o que está em jogo no deslocamento que levou da linguagem da guerra para o governo é precisamente a operacionalização da sua análise em termos de governamentalidade. Se o acontecimento que a genealogia faz emergir foi descrito não como "um campo fechado no qual se desenrolaria uma luta, um plano em que os adversários estariam em pé de igualdade; mas, sobretudo como [...] um 'não lugar', uma pura distância, o fato de que os adversários não pertencem ao mesmo espaço" (Foucault, 2001a, p. 1012). Isto é, se esse teatro de forças sem lugar é o que caracteriza o acontecimento, então é necessário considerá-lo quando Foucault afirma a governamentalidade como acontecimental, ou seja, designando a política menos como da ordem do combate do que da ordem de uma estratégia.

O poder, no fundo, é menos da ordem do enfrentamento entre dois adversários, ou do engajamento de um em relação ao outro, do que da ordem do "governo". [...] Portanto, o modo de relação própria ao poder não deve ser procurado nem do lado da violência e da luta, nem do lado do contrato e do laço voluntário (que não são mais que seus instrumentos): mas do lado desse modo de ação singular - nem guerreiro nem jurídico - que é o governo (Idem, p. 1056).

Em outras palavras, nem o modelo rousseauniano, nem o modelo schmittiano, nem a teoria do contrato, nem a teoria do partisan, servem para a construção de uma analítica do poder. Em um manuscrito inédito, citado por Senellart, Foucault definiu a governamentalidade como "uma generalidade singular" que não possui "outra realidade que não a 'acontecimental', e cuja inteligibilidade não coloca em funcionamento nada mais que uma lógica estratégica” (apud Senellart, 2004, p. 408).

Nos estudos sobre governamentalidade, o exercício do poder torna-se inteligível a partir de seu suporte móvel, de suas múltiplas formas de "correlações de forças que, dada sua desigualdade, induzem continuamente estados de poder [...] localizados e instáveis" (Foucault, 1993, p. 89). A própria instituição estatal é percebida não como realidade global, totalizante e universal ou como essência e fonte de onde o poder emana; o Estado é somente o efeito móvel de "transações incessantes que modificam, deslocam, revertem e alteram insidiosamente as fontes de financiamento, as modalidades de investimento, os centros de decisão, as formas e os tipos de controle, as relações entre poderes locais e autoridade central etc." (Foucault, 2004b, p. 79). Esse conjunto de realidades políticas, complexas e fundamentais para o funcionamento do Estado, escapa de uma abordagem globalizante e substancialista. Por isso a necessidade de substituir o termo majestoso e abstrato poder pela noção simples e concreta governo. A atividade do governo 
revela a maneira efetiva pela qual um poder é exercido, constituindo a realidade que permite substituir a questão essencialista "o que é o poder?" pela questão operatória "como o poder se exerce?". Essa seria uma análise genealógica do poder, descrito a partir de uma história efetiva ou a partir das práticas governamentais.

A governamentalidade é uma análise das práticas de governo tomadas em duas dimensões: uma tecnológica, por meio da qual o governo é analisado como tecnologia, como "conjunto de pessoas, técnicas, instituições e instrumentos para a condução da conduta" dos indivíduos (Miller e Rose, 2008, p. 16) - e nesse momento Foucault descreve, no curso de 1977-1978, uma história das tecnologias de segurança (polícia, planejamento urbano, população etc.) que foram colocadas em prática para "retomar e fazer funcionar, no interior de sua tática específica, elementos jurídicos, disciplinares, muitas vezes até mesmo multiplicando-os" (Foucault, 2004a, p. 10). A outra dimensão é "programática" e diz respeito aos diversos programas de governo e às racionalidades governamentais. No curso de 19781979, a análise da governamentalidade investiga a razão de Estado e o neoliberalismo como "instâncias da reflexão na prática de governar e sobre a prática de governar" (Idem, p. 4). Por sua vez, o curso seguinte, Du gouvernement des vivants, retoma essa segunda dimensão da governamentalidade, mas agora desdobrando-a no eixo verdade-subjetividade para estudar o governo dos homens pela verdade sob a forma da subjetividade e propor uma genealogia das formas modernas da obediência.

\section{Racionalidades governamentais}

A partir de 1980, os estudos da governamentalidade serão focados, sobretudo, na dimensão programática das artes de governar, isto é, sobre os programas e as racionalidades para dirigir as condutas. Para Foucault, o governo dos homens "supōe uma certa forma de racionalidade, e não uma violência instrumental" (2001b, p. 980).

O termo "racionalidades governamentais" convida a estabelecer paralelos com autores clássicos da sociologia, notadamente com Norbert Elias (1994) e Max Weber (1997), e suas expressóes respectivas de "processo civilizador" e "processo de racionalização ocidental". Em relaçãa aos estudos que Weber consagrou ao processo de racionalização, Rabinow e Dreyfus argumentaram que, não obstante a genealogia de Foucault permanecer na superfície das coisas para evitar precisamente a recorrência aos tipos ideais, às categorias gerais e às essências, "se não levamos em consideração os poucos pronunciamentos metodológicos de Weber - as diversas linhas dos tipos ideais - para a análise histórica, a distância entre Foucault e Weber diminui consideravelmente" (1995, p. 147). Na mesma direção, Mitchell Dean argumentou que o termo racionalização, considerado chave na sociologia weberiana, pode ter um uso apenas restrito para compreender os "diversos processos pelos quais formas particulares de saber são conectadas em 'regimes' ou sistemas organizados de práticas sociais heterogêneas" (Dean, 1994, p. 58). E argumenta que em Foucault o que existiria é um uso "minimalista" do termo racionalização, na medida em que está em questão não a razão como invariante antropológica, "mas a relação entre formas de racionalidade e as práticas a que elas estão vinculadas" (Idem, ibidem). Trata-se, portanto, de um uso no plural: são investigados as racionalidades ou os processos de racionalidades. Para Foucault o problema essencial é investigar o tipo de racionalidade empregado nas práticas, evitando considerar "a racionalização da sociedade ou da cultura como um todo", mas analisando "esse processo em vários domínios - cada um deles enraizados numa experiência fundamental: loucura, doença, morte, crime, sexualidade etc." (Foucault, 2001b, p. 954).

Embora as diferenças entre os dois pensadores sejam importantes, elas não impedem uma aproximação positiva, como fizeram Márcio Fonseca (2009), a partir da preocupação com a história nutrida por ambos os pensadores; e Szakolczai (1998), a partir da experiência como noção central em seus estudos sobre os processos de objetivação/subjetivação. Importa notar que em Foucault as racionalidades políticas não são da ordem da capacidade geral ou necessidade do sujeito humano, mas são antes o "produto específico de um conjunto de práticas sociais inscritas no interior de relaçôes de 'poder- 
saber" (Dean, 1994, p. 60). Um aspecto que o aproxima especialmente de Norbert Elias. ${ }^{1}$

Como observou Burguière, "o processo de civilização e, mais particularmente, a mudança modernizadora do Renascimento, descritos por Nobert Elias, prolongavam, para os historiadores franceses, a problemática introduzida por Philippe Ariès e Michel Foucault (mesmo que, na realidade, a obra do sociólogo alemão os tivesse precedido amplamente)" (2001, pp. 103-104). Em contrapartida, ambos pensaram a modernidade fora das estruturas do campo econômico e a partir de processos de racionalização. Para eles, as racionalidades alteram-se conforme as coerçôes relacionais que os indivíduos exercem uns sobre os outros. Nesse sentido, uma teoria geral da racionalização não seria pertinente, pois perderia de vista aquilo que a "racionalidade tem de próprio, o que as condições de sua formação têm de específico" (Colliot-Thélène, 2001, p. 38). Por essa razão, seria possível considerar que tanto em Elias como Foucault existe uma maior elaboração dos estudos das racionalidades políticas.

\section{Verdade e subjetividade}

Com o termo racionalidades Foucault entendia os conjuntos de prescriçōes calculadas e razoáveis que organizam instituiçôes, distribuem espaços e regulamentam comportamentos; as racionalidades provocam uma série de efeitos sobre o real. "São fragmentos de realidade que induzem efeitos de real tão específicos como aqueles da separação do verdadeiro e do falso na maneira pela qual os homens se 'dirigem', se 'governam', se 'conduzem' a si mesmos e aos outros" (Foucault, 2001b, p. 848). Portanto, é o problema da verdade que está em jogo nas racionalidades, e neste momento a questão central colocada por Foucault, no curso Do governo dos vivos, é a de saber

[...] como se fez para que, na cultura ocidental cristã, o governo dos homens exigiu da parte destes que são dirigidos, além de atos de obediência e submissão, "atos de verdade" que têm a particularidade de que não somente o sujeito é solicitado a dizer a verdade, mas dizer a verdade a propósito dele mesmo, de suas faltas, de seus desejos, do estado de sua alma etc.? Como formou-se um tipo de governo dos homens no qual não se é solicitado simplesmente a obedecer, mas a manifestar, enunciando-o, aquilo que se é? (Idem, p. 944).

Ao dar uma resposta, Foucault retomou a noção de regime de verdade, elaborada pela primeira vez em 1976, para compreender a maneira pela qual "a verdade está ligada circularmente a sistemas de poder que a produzem e a sustentam, e a efeitos de poder que ela induz e que a reconduzem" (Idem, p. 114). Por regime de verdade, Foucault quer indicar a existência de um dispositivo da verdade segundo o qual os discursos não apenas funcionam como verdadeiros, mas também os mecanismos, as instâncias e os modos para distinção entre o falso e o verdadeiro são definidos; os procedimentos e as técnicas para obtenção da verdade são produzidos; o estatuto daqueles que dirão a verdade é definido. Investigar regimes de verdade é descrever o funcionamento político desse dispositivo. "O que faço [dizia Foucault em 1978] não pertence nem à história, nem à sociologia, nem à economia. [...] É uma política da verdade" (2004a, p. 5).

Em qualquer sociedade existe uma política da verdade. Nas sociedades ocidentais, ela constituiu uma das condiçōes para a formação do capitalismo: a verdade é necessária para a produção de riquezas e de poder político. Não obstante, os regimes de verdade não são simplesmente ideológicos ou superestruturais: é aquilo cuja ausência torna um regime político inconstante, mas cuja presença o torna perigoso (Foucault, 2001b, p. 1497). Daí as inúmeras batalhas pela verdade, inúmeras lutas por esses regimes cuja função é a de constringir os indivíduos a determinados atos de verdade. Foucault compreende a expressão "atos de verdade" com base no conceito de exomologese do cristianismo primitivo. Um ato de verdade designa o

[...] ato destinado a manifestar simultaneamente uma verdade $\mathrm{e}$ a adesão do sujeito a essa verdade. Fazer a exomologese de sua crença não é simplesmente afirmar o que se crê, mas afirmar 
o fato dessa crença; é fazer do ato de afirmação um objeto de afirmação e, portanto, autenticálo seja em si mesmo, seja diante dos outros. A exomologese é uma afirmação enfática, cuja ênfase se aplica antes de tudo sobre o fato de que o próprio sujeito se liga a essa afirmação, aceitando suas consequências (Idem, p. 945).

A exomologese foi indispensável ao cristianismo, pois por meio dela o cristão aceitou as verdades que lhe foram reveladas e ensinadas, estabelecendo uma relação de obrigação e engajamento. "Obrigação de manter suas crenças, de aceitar a autoridade que as autentica, de fazer eventualmente profissão pública, de viver em conformidade com elas etc." (Idem, ibidem). Um regime de verdade define-se por uma relação de obrigação e de engajamento entre sujeito e verdade, pela junção entre a obrigação e o engajamento dos indivíduos com os procedimentos de manifestação do verdadeiro. Foucault confere à expressão "regime de verdade" a mesma realidade concedida aos termos "regime político", "regime jurídico", "regime penal" etc.

Fala-se de regime penal designando por ele um conjunto de procedimentos e instituiçóes pelos quais os indivíduos estão constrangidos a se submeterem à leis de validade geral. Bom, então nessas condições, por que efetivamente não se poderia falar de regimes de verdade para designar o conjunto de procedimentos e instituições pelas quais os indivíduos são engajados e constrangidos a colocar, sob certas condiçôes e para certos efeitos, atos bem definidos de verdade? Por que, depois de tudo, não se poderia falar de obrigações de verdade do mesmo modo que existem constrangimentos políticos ou obrigaçôes jurídicas? (Foucault, 2010, p. 68).

Ao transferir a noção de regime para o problema da verdade, o objetivo é afirmar a coação política das obrigaçōes de verdade destinadas a impor atos de crença, de profissão de fé, de confissōes, de convicçôes, de convencimentos, de persuasōes e de engajamentos. Entretanto, nesse empreendimento, Foucault deparou-se com um aspecto importante da doutrina espinosista da verdade, o verum index sui. Em sentido inverso, Espinosa havia sustentado que "a obediência contempla a vontade daquele que comanda, não a necessidade e a verdade da coisa" (2003, p. 246, grifo meu). Desse modo, as leis de Deus somente se apresentam como direito instituído quando se ignora suas causas; na medida em que são aceitas como verdade, sua

[...] obediência passa imediatamente a ser amor, que brota do conhecimento verdadeiro com a mesma necessidade com que a luz jorra do sol. Conduzidos pela razão, podemos, pois, amar a Deus, mas não obedecer-lhe, uma vez que não podemos aceitar o direito divino, enquanto ignoramos a sua causa, como divino, nem podemos pela razão conceber Deus como um príncipe a promulgar leis (Espinosa, 2008, p. 137).

Em outras palavras, para Espinosa, a própria verdade é a norma de si mesma e dispensa qualquer tipo de coação, tal como faz a luz ao revelar as trevas e a si mesma: a ideia verdadeira é norma de si, verum index sui.

A definição de Espinosa da verdade como norma de si mesma coloca a noção de regime de verdade empregada por Foucault num impasse, tornando-a válida apenas para designar práticas em que o verdadeiro esteja ausente. $\mathrm{Na}$ definição espinosista da verdade, a coação na exomologese cristã é exercida pelo não verdadeiro, pelo não verificável, enfim, por aquilo que não pode ser demonstrado. Porque, se a verdade não tem realmente poder de obrigação, a coação se faz necessária somente para que uma não verdade como a da ressurreição da carne produza seus efeitos de vínculo e de obrigação. Se a verdade é o índice de si mesma, então ela não tem necessidade de regimes de obrigação com a função de torná-la verdadeira pela força de sujeiçãa. A definição de Espinosa tornaria a noção foucaultiana de regime de verdade inadequada.

Contudo, Foucault procurou demonstrar a operacionalidade de seu conceito e as possibilidades analíticas que ele implica. Seu argumento é que a afirmação segundo a qual o que coage na verdade é o verdadeiro em si mesmo oculta e exclui da análise 
uma distinção importante. Se, de um lado, o verdadeiro é o index sui, no significado propriamente espinosista, de outro, isso não implica que

[...] a verdade seja rex sui, que a verdade seja lex sui, que a verdade seja judex sui. Quer dizer, que não é a verdade que é detentora e criadora dos direitos que ela exerce sobre os homens, das obrigações que esse tem a seu respeito e dos efeitos que eles esperam dessas obrigações, uma vez que e na medida em que se completam. Em outras palavras, não é a verdade que de qualquer modo administra seu próprio império, julga e sanciona esses que a obedecem e desobedecem. Não é verdade que a verdade não constrange a não ser pela verdade (Foucault, 2010, p. 71).

Não é porque a verdade seja o índice de si, verum index sui, isto é, que seja capaz de atestar por si mesma e, no ato de atestar, revelar, derrotar, suprimir o que lhe é oposto, isso não implica que ela se torne, por extensão, soberana de si, legisladora de si, juíza de si. Seja qual for o raciocínio, seja qual for a evidência que o recubra, seja qual for sua intensidade demonstrativa ou a constância da sua proposição, "existe sempre e é preciso sempre supor uma certa afirmação que não é da ordem da lógica, da constatação ou da dedução; uma afirmação que não é da ordem do verdadeiro e do falso, mas que é muito mais uma espécie de engajamento, de profissão que consiste em dizer: é verdade, logo, eu me inclino" (Idem, ibidem).

Este "logo" [donc], segundo Foucault, não pertence à lógica e não repousa sobre nenhuma evidência, nem tampouco é unívoco. Ao contrário, o termo se apresenta como uma proposição um tanto enigmática e como um fenômeno de tipo histórico, muito mais do que uma consequência inerente à lógica.

Esse "portanto" que liga o "é verdadeiro" e o "eu me inclino" e que dá o direito à verdade de dizer: você é forçado a me aceitar porque eu sou a verdade; nesse "portanto", nesse "você é forçado, você é constrangido, você deve se inclinar"; nesse "você deve" da verdade exis- te qualquer coisa que não advém da verdade por ela mesma. O "você deve" em termos de verdade, imanente à manifestação da verdade, é um problema que a ciência por ela mesma não pode justificar e levar em conta. Esse "você deve” é um problema histórico-cultural que creio fundamental (Idem, ibidem).

Foucault sugere o exemplo de dois lógicos discutindo e a maneira pela qual o raciocínio conduzirá a uma proposição reconhecida por ambos como verdadeira, mesmo que um deles no início da discussão tenha negado a verdade dessa proposição. Um dos lógicos que, no início da discussão negou a verdade, e que ao final a reconhece, dirá, explícita ou implicitamente: "é verdade, logo, eu me inclino". O que ocorreu? Segundo Foucault, duas coisas muito distintas. O que levou um dos lógicos a dizer "é verdade", foi simplesmente o fato de a proposição ser lógica: se a proposição lhe pareceu verdadeira, foi em razão da lógica escolhida, de suas regras, seus axiomas, sua gramática. Para que uma proposição seja verdadeira, basta, é suficiente e é necessário que exista a lógica com suas regras de construção e de sintaxe. Nesse sentido, uma das proposições foi reconhecida como verdadeira não porque os debatedores são lógicos, mas porque tal proposição pareceu-lhes estar mais conforme a lógica previamente adotada: "foi a lógica, definida na sua estrutura particular, que assegurou o fato de que a proposição seja verdadeira" (Idem, p. 72) Porém, outra coisa muito distinta ocorre quando é dito: é verdade portanto eu me inclino:

[...] esse "portanto" não pertence à lógica: não é a verdade da proposição que o constrange efetivamente; é porque ele é lógico, ou melhor, é na medida em que ele faz lógica [...]. Quer dizer, é porque ele se constituiu a si mesmo ou porque ele foi convidado a se constituir como operador, num certo número de práticas ou como parceiro num certo número de jogos e encontrando nesse jogo uma lógica tal, é nestes termos que o verdadeiro será considerado como um vínculo em si mesmo, e sem outra consideração, com valor constringente (Idem, p. 73). 
O problema é que a tradição filosófica do Ocidente tomou a conjunção cartesiana logo colocada entre o "eu penso" e o "eu existo" como algo teoricamente inatacável. Sem perceber, entretanto, que tal conjunção ocultava um segundo sentido implícito, contido, precisamente, na ideia "é verdade, logo, eu me inclino". Segundo Foucault, este segundo sentido pertence aos regimes de verdade e não é redutível ao caráter intrínseco do verdadeiro; ao contrário, resulta da aceitação do regime de verdade por um sujeito:

Para que esse regime de verdade seja aceito é preciso que o sujeito que pensa seja qualificado de uma certa maneira. Quer dizer que esse sujeito pode muito bem ser submetido a todos os erros possíveis, a todas as ilusōes possíveis dos sentidos; esse sujeito pode mesmo ser submetido a um mau raciocínio que o engana. Não obstante, existe uma condição. Para que a máquina funcione, e para que o "portanto" do "eu penso portanto existo" seja um valor provável, é preciso vinculá-lo a um sujeito que possa dizer: quando isso for verdadeiro, e evidentemente verdadeiro, eu me inclinarei! É preciso de um sujeito que possa dizer: "é evidente portanto eu me inclino!" Quer dizer, é preciso de um sujeito que não seja louco (Idem, pp. 73-74).

A exclusão da loucura foi um dos efeitos maiores na organização dos regimes de verdade no Ocidente. Do mesmo modo que

[...] não existe rei em geometria, quer dizer que nenhum suplemento de poder não é útil nem necessário para fazer geometria [...] tampouco deve haver visōes da loucura na filosofia ou em qualquer outro sistema racional: não é preciso existir loucos, quer dizer, não é preciso existir pessoas que não aceitem o regime de verdade (Idem, p. 74).

Aqui Foucault introduziu sua postura anarqueológica. A partir da noção de regime de verdade, a anarqueologia ganha duas dimensōes: de um lado, ela é um método analítico para o estudo dos regimes de verdade; de outro, consiste igualmente em um gesto que rejeita o poder de obrigação e a força de coação que o verdadeiro pretende sobre os homens. Nessa dimensão, o foco da análise é deslocado do "é verdadeiro" para a força que ele implica. A anarqueologia dos saberes não consiste em descrever a história da ciência para mostrar que, se a verdade coage os homens, compensa-os desfazendo seus sonhos e fantasias, celebrando seus desejos, desenraizando suas representações. Ao contrário, uma história anarqueológica consiste em recusar previamente o direito de obrigação e a força de coação que o verdadeiro pretende sobre os homens.

Dessa maneira, na anarqueologia está em questão tanto uma "postura metodológica" como uma "atitude filosófica" de transgressão perante o poder da verdade. A anarqueologia é uma atitude e uma postura intelectual que inverte a posição tradicional da filosofia em relação à verdade. Desde Platão, a posição da filosofia tem sido a de aceitar o poder da verdade. Segundo Foucault, essa posição filosófica tradicional pode ser descrita nos seguintes termos: a partir da ligação voluntária que o sujeito estabelece com a verdade, ligação que the fornece os fundamentos, os instrumentos e as justificaçôes com as quais o sujeito sustentará um discurso de verdade; a partir dessa ligação voluntária, a filosofia questiona o que esse sujeito pode dizer sobre, para ou contra o poder que o submete. Contra essa posição da filosofia clássica, Foucault apresentou a postura anarqueológica, no sentido de que é preciso recusar a ligação voluntária com a verdade para colocar como problema inicial o questionamento do poder. Ou seja, iniciar a análise com um ato de questionamento do poder para perguntar:

[...] o que esse gesto sistemático, voluntário, teórico e prático de colocar em questão o poder tem a dizer sobre o sujeito de conhecimento e sobre a ligação com a verdade na qual involuntariamente ele se encontra preso? Dito de outro modo, não se trata mais de dizer: considerando o vínculo que me liga voluntariamente à verdade, o que é que eu posso dizer do poder? Mas, considerando minha vontade, decisão e esforço de desfazer a ligação que me liga ao poder, o que é [feito] então do sujeito de conhecimento e da verdade? (Idem, p. 60). 
Ato de transgressão ao poder e posição analítica que apresenta o gesto de desobediência como ponto de partida da análise. No começo dos anos de 1970 Foucault $(1973$, fl. 16) havia tomado o sistema das táticas punitivas como analisador das relações de poder, afirmando que nesse procedimento a luta seria considerada o elemento central da análise. Em seguida, no começo dos anos de 1980, ele afirma que "é o movimento para separarse do poder que deve servir de revelador da transformação do sujeito e das relações que ele mantém com a verdade" (2010, p. 60). Desta vez, o elemento central da análise é o ato de transgressão, de desobediência, um anarquismo epistemológico. O neologismo anarqueologia foi introduzido por Foucault para ensaiar em que medida a anarquia e o anarquismo podem sustentar e pôr em funcionamento um discurso crítico contra o poder (Idem, p. 61). Durante uma conferência de 1978, pronunciada na Sociedade Francesa de Filosofia, Foucault destacava precisamente esse caráter anárquico entre as modalidades históricas possíveis da crítica. Na crítica, o sujeito afirma seu direito de interrogar a verdade, com seus efeitos de poder, e o poder, com seus discursos de verdade. Nesse sentido, a crítica pode ser tomada como "a arte da não servidão voluntária e da indocilidade refletida”, assumindo como "tarefa a não sujeição no jogo do que se poderia chamar, em uma palavra, a política da verdade" (Foucault, 1990, p. 39).

A perspectiva anarqueológica integra, a partir dos anos de 1980, um conjunto mais amplo de pesquisas sobre a noção do "governo dos homens pela verdade" iniciada por Foucault no curso Do governo dos vivos. No entanto, trata-se de uma noção que permanece praticamente inédita, assim como o curso em que foi pela primeira vez elaborada. ${ }^{2} \mathrm{O}$ melhor estudo que se tem notícia acerca da anarqueologia foi realizado pela feminista espanhola Maite Larrauri (1989; 1999). Em seguida, a noção é retomada por Negri e Hardt ao transcreverem a passagem que os autores atribuíram a Foucault: "anarcheology - the method that takes no power as necessarily acceptable (Du Gouvernement des Vivants)" (1994, p. 292). E, por fim, a anarqueologia foi também citada em Szakolczai (1998, p. 247) como "anarcheology of power".
A anarqueologia é também a retomada de uma preocupação central na reflexão do pensador anarquista francês Pierre-Joseph Proudhon. Desde 1840, quando publica $O$ que é a propriedade?, obra que o consagrou como fundador do anarquismo moderno, Proudhon colocou no foco de sua investigação sobre o governo dos homens o problema da subjetividade. Segundo ele, existe um fato psicológico frequentemente negligenciado pelos filósofos. Trata-se do "poder do hábito de imprimir novas formas categoriais no entendimento, tomadas nas aparências que nos impressionam e desprovidas, na maior parte das vezes, de realidade objetiva, e cuja influência no nosso julgamento não é menos predeterminante que as das primeiras categorias", as estabelecidas por Aristóteles e Kant (Proudhon, 1997, p. 15-16).

Para Proudhon, a preocupação e a adesão que resulta desses princípios são tão fortes, que mesmo combatendo-os, raciocina-se segundo eles: "obedecemos-lhes atacando-os". Funcionam como uma espécie de círculo fechado do entendimento no qual a inteligência opera. Por essa razão, bastaria que os homens determinassem mal a ideia do justo e do direito para que suas aplicações legislativas fossem falsas ou incompletas e sua política injusta e nefasta. Tratase, portanto, de princípios e categorias dotados de realidade, ou melhor, que contém o real, que fazem existir o real, isto é, que possuem força performativa. Segundo Proudhon, esse fato é específico ao conhecimento e aos efeitos que provoca na subjetividade, visto ser ela o principal elemento em questão quando se passa das ciências naturais para o mundo moral.

Seja qual for o sistema que adotemos sobre a causa do peso e a forma da Terra, não se afeta a física do globo [...]. Mas é em nós e por nós que se cumprem as leis da nossa natureza moral: ora, essas leis não podem ser executadas sem a nossa participação pensante, sem que as conheçamos (Idem, p. 18).

Após assistir atônito a primeira revolução popular na história da França entregar o governo da nação nas mãos do aventureiro Luís Bonaparte, Proudhon lança, em novembro de 1849 nas páginas de seu jornal La Voix du Peuple, o seguinte questionamento: 
Por que acreditamos no governo? Do que procede, na sociedade humana, essa ideia de autoridade, de poder; essa ficção de uma pessoa superior, chamada Estado? Como se produz essa fiç̧ão? Como se desenvolve? Qual é sua evolução, sua economia? [...] Não seria [o governo] uma daquelas concepções primevas de nosso entendimento? (Proudhon, 1947, p. 15).

Em suma, de onde provém a predisposição mental que fez com que "as revoluçōes mais liberadoras e as efervescências de liberdade terminassem constantemente com um ato de fé e de submissão ao poder"? (Proudhon, 1979, p. 87). Provém da força de uma ideia: o princípio de autoridade. Essa resposta valeu a Proudhon o epíteto de idealista e metafísico. Não obstante, dedicou uma parte substancial da sua obra para demonstrar a força de impulsão do princípio de autoridade no exercício do governo.

\section{Genealogia da obediência}

O propósito da anarqueologia foi tornar mais operatório o tema saber-poder. O deslocamento na analítica do poder que levou do tema guerra para o do governo possibilitou a Foucault considerar na análise a multiplicidade dos regimes de verdade e a maneira pela qual vinculam de modo constringente a manifestação do verdadeiro e os sujeitos que nela operam. A partir disso, foi possível questionar:

Como os homens, no Ocidente, foram ligados ou conduzidos a ligarem-se a manifestaçôes bem particulares de verdade nas quais são precisamente eles mesmos que devem ser manifestados em verdade? Como o homem ocidental foi ele mesmo ligado à obrigação de manifestar em verdade àquilo que ele mesmo é? Como foi ele ligado, de qualquer modo, a dois níveis e de dois modos: de um lado, à obrigação de verdade e, de outro, ao estatuto de objeto no interior dessa manifestação de verdade? Como foram eles ligados à obrigação de ligarem a si mesmos como objeto de saber? (Foucault, 2010, p. 76)
É esse double bind que o método anarqueológico procura investigar, tornando explícita a maneira como regimes de verdade estão sempre conectados com regimes políticos, jurídicos, penais etc. Ao explicitar a não separação entre político e epistemológico, a anarqueologia ajuda a compreender o modo pelo qual um regime penal é também um regime de verdades sobre o preso; um regime manicomial impóe um regime de verdades sobre o louco; enfim, um regime governamental estabelece necessariamente um regime de verdades sobre os súditos, os cidadãos, os sujeitos do governo: seus direitos, suas obrigaçōes etc. É nesse sentido que a anarqueologia coloca em questão o problema histórico da prática da obediência.

Por que e como o exercício do poder em nossa sociedade, o exercício do poder como governo dos homens, exige não somente atos de obediência e de submissão, mas atos de verdade [...]? Por que nessa grande economia das relaçōes de poder se desenvolveu um regime de verdade indexado à subjetividade? Por que o poder, e isso desde milênios em nossa sociedade, exige que os indivíduos digam não somente "eu obedeço", mas lhes exige ainda que digam: "eis aquilo que eu sou, eu que obedeço; eis o que eu sou, eis o que eu quero, eis o que eu faço (Idem, p. 66).

Para empreender essa genealogia das formas de obediência na modernidade, Foucault reportou-se aos primeiros Padres da Igreja. Por que esse longo recuo histórico ao cristianismo primitivo? Por duas razôes ao menos: primeiro, porque anteriormente o que havia eram culturas pagãs, isto é, experiências greco-romanas muito diferentes da nossa e em relação às quais nossas formas de obediência encontram pouca correspondência. Já posteriormente ao cristianismo primitivo, tem-se a Igreja católica constituída sob sua forma institucional definitiva. Assim, para Foucault importava se posicionar precisamente no intervalo entre o paganismo e a instituição universal da Igreja com o intuito de perceber quais foram os processos que, rompendo com o passado, puderam preparar o futuro institucional do catolicismo. Para investigar as descontinuidades 
existentes entre as culturas pagãs e o cristianismo, Foucault estudou a constituição e as práticas nos monastérios.

Retomando a descrição feita por João Cassiano (1872, pp. 53ss) das comunidades cenobitas e das inúmeras provas de submissão pelas quais o noviço é admitido no monastério, Foucault mostrou como na direção do noviço a formação recaía essencialmente sobre o aprendizado da obediência. Por meio dessa formação, o noviço deveria aprender a vencer sua vontade, e para esse fim seu mestre deveria dar-lhe ordens contrárias às suas inclinações para que obedecesse e para que, nessa obediência, sua vontade fosse vencida. Essa técnica visava a uma obediência exaustiva e perfeita, capaz de fazer o noviço percorrer pelo discurso todos os segredos de sua alma e fazer com que viessem à luz: nessa emersão, a obediência ao outro seria total, exaustiva e perfeita. "Obedecer tudo e nada esconder" ou "nada querer por si mesmo e tudo dizer de si mesmo": foi a junção desses dois princípios que, segundo Foucault, esteve no coração da instituição monástica, bem como de uma série de práticas e de dispositivos que informaram a constituição da subjetividade no Ocidente.

Cassiano cita vários exemplos de ordens absurdas, no entanto indicativas do "espírito e sinceridade da obediência”. Havia um caso famoso do abade João, habitante de Licon, deserto de Tebaida. Cassiano ressalta sua "admirável obediência” com a seguinte narrativa:

Seu superior apanha na sua dispensa um pequeno bastão talhado para instrumento de cozinha e que, não mais servindo, estava não somente seco como quase apodrecido. Finca-o na terra na presença de João e lhe ordena buscar água duas vezes por dia para irrigá-lo, a fim de que a umidade desenvolvesse nele raízes, que o verdejasse, que sua folhagem confortasse os olhos e que sua sombra beneficiasse àqueles que fossem ali repousar durante o calor do verão. O discípulo recebe a ordem com o respeito ordinário, sem pensar na inutilidade da sua obediência. Saía todos os dias à procura de água a mais de duas milhas e jamais deixou de irrigar o bastão durante um ano inteiro; a doença, as festas, as ocupações mais imperativas que poderiam desobrigálo, mesmo os rigores do inverno, não o impediram uma única vez de fazer o que tinha sido ordenado. Seu velho mestre observava em silêncio a assiduidade de seu discípulo e a maneira como obedecia com grande simplicidade de coração e humildade sincera, sem nenhuma feição de contrariedade no rosto, sem murmurar ou raciocinar, como se a ordem tivesse vinda do céu (Idem, pp. 71-72).

Por fim, acrescenta que "o jovem religioso, formado em uma semelhante escola, fez tamanhos progressos nessa virtude e brilhou de tal maneira por sua humildade, que sua reputação se espalhou como bom odor por todos os monastérios" (Idem, ibidem). ${ }^{3}$

Na prática cenobita, observa Foucault, a obediência não é estabelecida em vista de um objetivo exterior à relação de obediência. Obedece-se simplesmente para poder tornar-se obediente, para produzir um estado de obediência permanente e definitivo, que seja capaz de durar mesmo quando não houver ninguém a quem se deva obedecer, e até mesmo antes de alguém formular uma ordem. Estado de obediência significa, portanto, que a obediência não é uma maneira de reagir a uma ordem. A obediência não é simplesmente a resposta a alguém: é e deve ser uma maneira de ser anterior a qualquer ordem e mais fundamental que qualquer situação de comando. $\mathrm{O}$ estado de obediência deve antecipar, de alguma maneira, as relaçóes com o outro: antes mesmo que esse outro esteja presente e que ordene, já se estará em estado de obediência. $\mathrm{Na}$ relação entre noviço e mestre, a obediência não é uma passagem na vida, é um estado no qual é preciso permanecer até o fim da vida sob o olhar de quem quer que seja.

Essa obediência que é, portanto, condição, substrato permanente e efeito da direção, Cassiano a caracteriza de três maneiras. Primeiramente, isso que ele chama a subjectio, a submissão, o fato de ser sujeito. Subjectio quer dizer o que exatamente? Quer dizer duas coisas: quer dizer que o monge, em tudo que ele faz, deve 
ser submisso à regra ou a seu superior ou a seus companheiros ou aos eventos que podem se produzir. Significa que não somente ele recebe ordens, mas ele age de maneira que tudo toma a forma e o valor de uma ordem. No fundo, o monge vive num mundo que é povoado por ordens: todo terceiro, todo evento, deve funcionar como uma ordem que é dada e o monge deve reagir a eles como uma ordem. Tudo sendo ordem para ele, também cada um dos atos que ele comete deve se inscrever no interior dessa estrutura de ordem (Foucault, 2010, p. 100).

As técnicas que permitirão ao monge aceder a este estado de obediência perfeita incidem menos sobre o comportamento real do noviço do que sobre o fluxo incessante dos pensamentos que penetram sua consciência e que, em virtude de sua multiplicidade, perturbam "a unidade necessária da contemplação” (Foucault, 2001b, p. 996). A isso respondeu a existência, nas práticas cristãs da direção de consciência, de um dispositivo ligando três elementos: "o princípio da obediência sem fim, o princípio do exame incessante e o princípio da confissão exaustiva. Um triângulo: escutar o outro, observar a si mesmo, falar ao outro de si mesmo" (Foucault, 2010, p. 106). Trata-se do dispositivo da confissão.

Ao descrever a genealogia das formas modernas da obediência, Foucault descobriu a enorme importância política do dispositivo da confissão para o exercício do governo nas sociedades ocidentais. Esse aspecto permite compreender o lugar central que o curso de 1980 ocupa no retournement efetuado por Foucault a partir do segundo volume da sua História da sexualidade para estudar as técnicas de si na cultura greco-romana. Como observou Landry (2007, p. 31), as liçôes do curso Do governo dos vivos figuram como o alicerce conceitual da obra intitulada Les aveux de la chair [As confissóes da carne], que deveria integrar a série de volumes da História da sexualidade. Após publicar o primeiro volume, A vontade de saber, em 1976, o projeto inicial de Foucault era investigar as práticas de confissão do cristianismo primitivo em um segundo volume. Como é sabido, o projeto é alterado e o segundo volume da série foi ocupado pelo livro $O$ uso dos prazeres e que foi, em seguida, desdobrado em um terceiro volume, $O$ cuidado de si. Dessa forma, deslocado para ocupar o quarto volume da série, $A s$ confissóes da carne não foi publicado nem jamais o será, pelo fato de Foucault ter deixado seus manuscritos sem revisão e a indicação testamentária de nenhuma obra póstuma. Não obstante, embora inéditos, os manuscritos foram descritos pelo editor de Foucault como constituindo la clé de voûte do conjunto.

Todavia, uma parte da problemática do curso foi também amplamente retomada no seminário "Sexuality and solitude", ministrado com o sociólogo Richard Sennett na Universidade de Nova York, em novembro de 1980. Assim como o curso no Collège de France, no seminário de Nova York Foucault analisa o cristianismo como a prática que incide fundamentalmente sobre uma técnica de confissão e sobre um modo de obrigação de verdade, abordando a espiral cristã que levou da formulação da verdade à renúncia da realidade; um movimento que, segundo ele, constitui o núcleo das práticas de si cristãs. "Quanto mais descobrimos a verdade sobre nós mesmos, mais devemos renunciar a nós mesmos; e quanto mais queremos renunciar a nós mesmos, mais será para nós necessário revelar a realidade de nós mesmos" (Foucault, 2001b, p. 991). A espiral infinita verdade/realidade de si colocava para Foucault o problema de compreender os motivos pelos quais, na cultura cristã, a sexualidade se tornara o "sismógrafo" da subjetividade.

Foi a experiência da sexualidade que conduziu a investigação das relações verdade/subjetividade para um plano analítico novo. Como precisou Foucault em seu último curso no Collège de France, a questão da sexualidade tornou necessário confrontar essas relações de outra forma: "não sob a forma do discurso que diz a verdade sobre o sujeito, mas na forma do discurso de verdade que o sujeito é suscetível e capaz de dizer sobre si mesmo, [sob] um certo número de formas culturalmente reconhecidas e tipificadas, como por exemplo o testemunho, a confissão, o exame de consciência" (2009, p. 5). A sexualidade emergiu como o domínio no qual o poder da verdade sobre a subjetividade aparece de modo mais evidente no interior da problemática 
do "governo de si e dos outros". Com ela, tem-se um domínio em que os deveres da interdição e os direitos do permitido dividem o espaço de seu império com uma multiplicidade de sentimentos representados, de pensamentos e desejos suscitados. Esse aspecto introduz uma diferença sensível entre as formas de interdição relativas aos outros domínios, tais como a loucura, a doença, a criminalidade, visto que, contrariamente a esses interditos, as interdições sexuais estão sempre ligadas à obrigação de dizer a verdade sobre si.

A propósito do sexo e do desejo, o discurso verdadeiro se organizou em torno de um discurso de confissão sobre uma parte de si mesmo indissociável daquilo que se é. Discurso de confissão de uma parte indissociável de si: é em torno disso que é preciso compreender o problema da relação entre subjetividade e verdade a propósito do sexo. Com relação à loucura, à doença, à morte e ao crime, o problema é saber qual experiência de si e dos outros é possível no momento em que existe alguém com o direito de dizer: "este é louco; vocês são doentes; aquele é criminoso". Com a sexualidade o problema que eu gostaria de colocar é: qual experiência de si consigo é possível, ou qual é o tipo de subjetividade implícita ao fato de que nós estamos sempre na possibilidade e no direito de dizer: "sim, é verdade, eu desejo!". Trata-se, em suma, de estudar a maneira pela qual o sujeito é chamado a se manifestar e a se reconhecer a si mesmo, no seu próprio discurso, como sendo um verdadeiro sujeito de desejo (Foucault, 1981, Fita 1, Lado B).

A partir da experiência sexual, Foucault percebeu o grau de sofisticação em que se deu a articulação entre o político e o epistemológico, entre poder e verdade. Foi em relação à sexualidade que manifestaram-se, de maneira específica e bem elaborada, as relações entre o governo dos homens, a verdade e os modos de subjetivação. A sexualidade revela a maneira pela qual se desenhou, no Ocidente, o governo dos homens pela verdade que eles efetuam em si mesmos; com ela e por meio dela, pela primeira vez na história, foi estabelecido um laço profundo entre exercício do poder e obrigação por parte dos indivíduos de constituírem a si mesmos como atores, espectadores e objetos da verdade. Dessa maneira, o tipo de prática ligada ao domínio da sexualidade introduziu essa espécie de dupla sujeição, tornada em seguida absolutamente fundamental para a política e para o exercício do poder nas sociedades ocidentais: sujeição ao poder e sujeição à verdade. Daí os "dois sentidos da palavra 'sujeito': sujeito submetido a um outro pelo controle e dependência, e sujeito preso à sua própria identidade pela consciência ou pelo conhecimento de si” (Foucault, 2001b, p. 1046).

A perspectiva anarqueológica do último Foucault influenciou fortemente, a partir dos anos de 1990, uma extensa literatura que deu origem a um novo campo de saber intitulado Queer Theory (Watson, 2005). Seu desenvolvimento se deu pela crítica das limitaçôes das identidades gay e lésbica, entre as quais se destacam as contribuiçōes de Eve Sedgwick (2007), problematizando as oposiçōes minoritarizantes e universalizantes da definição homo/heterossexual como presas às questôes de identidade, e David Halperin (1995), para quem a noção Queer designa não uma identidade, mas uma posicionalidade [positionality] em face da norma. Na teoria Queer, como afirmaram Richard Miskolci e Júlio Simões, é o próprio regime da sexualidade que é colocado em questão, na medida em que problematiza

[...] os conhecimentos que constroem os sujeitos como sexuados e marcados pelo gênero, e que assumem a heterossexualidade ou a homossexualidade como categorias que definiriam a verdade sobre eles. De modo geral, o sistema moderno da sexualidade é encarado, da perspectiva queer, como um conjunto de saberes e práticas que estrutura a vida institucional e cultural de nosso tempo (2007, p. 11).

Além disso, no Brasil, a perspectiva foucaultiana encontrou outra forte ressonância nos estudos feministas, sobretudo com os trabalhos de Margareth Rago, procurando desfazer "as ardilosas estratégias de produção normativa da figura feminina pelos discursos médicos e jurídicos, extremamente 
moralistas e conservadores, assim como pela literatura e pela propaganda" (Rago, 2008, p. 188).

A velha técnica confessional cristã para a produção de obediência não desapareceu. Seu uso foi talvez enfraquecido em um contexto em que se tornou suficiente a temerosa figura do Príncipe para extração da obediência dos súditos. Porém, a hipótese sustentada nas últimas investigaçôes de Foucault é de que o funcionamento das democracias e das sociedades liberais exigiu também o restabelecimento e a maximização daquelas técnicas de si inventadas pelo cristianismo. Todavia, tratou-se de um restabelecimento e maximização não mais restritos à instituição dos mosteiros, mas expandidos para uma vasta rede de instituiçôes e relaçôes sociais que vão da família às prisões. No interior de cada uma dessas instituiçôes, assim como nas relaçôes sociais mais espontâneas, adquiriu-se o hábito de confessar aquilo que se é. Entretanto, a confissão moderna já não tem por função a renúncia de si, como queriam os primeiros Padres da Igreja. Confessa-se hoje com a função de revelar e reafirmar incessantemente identidades positivas, tais como as de pai, marido, professor, aluno, operário, doente, criminoso. Essa revelação/reafirmação confessional permanente de si, advertiu Foucault, é um dos principais suportes da nossa obediência moderna: é o que produz subjetividades suficientemente obedientes exigidas pelo bom funcionamento das sociedades neoliberais.

Quaisquer que tenham sido as formas assumidas pela obrigação de dizer a verdade sobre si mesmo e de se reconhecer nessa verdade, a obrigação jamais cessou: obriga-se a falar de si mesmo para dizer a verdade. Nessa obrigação, o discurso de verdade constituiu uma das grandes linhas de força na organização da subjetividade ocidental: é solicitado e incitado por todo um sistema institucional, cultural, religioso, social. Se na tragédia de Sófocles, diz Foucault, para conhecer a verdade sobre si, Édipo teve que extorqui-la do alto de seu poder real da boca de um escravo, em nossa atualidade a obrigação de dizer a verdade sobre si dispensa o exercício violento de qualquer poder: basta interrogar a si mesmo no interior de uma estrutura de obediência. Essa verdade trazida no fundo de si e acoplada profundamente ao segre- do de si será indefinidamente incitada a se mostrar para alguém. Se isso ocorre, é porque a fixação em discurso de verdade daquilo que se é não constitui simplesmente uma obrigação essencial, mas é também uma das formas primeiras e fundamentais $\mathrm{da}$ nossa própria obediência.

\section{Notas}

1 Segundo Daniel Defert (2001, p. 88), entre outubro e novembro de 1983, Foucault pretendeu traduzir, com Martin Ziegler, a obra de Norbert Elias: Die Einsamkeit des Sterbenden [A solidão dos moribundos].

2 Ao leitor brasileiro é possível aproximar-se das instigantes elaboraçōes de Foucault, realizadas no curso de 1980, pelos excertos recentemente publicados em Foucault (2010).

3 Cf. o mesmo exemplo citado em Foucault (2004a, pp. 179-180).

\section{BIBLIOGRAFIA}

BURGUIÈRE, André. (2001), "Processo de civilização e processo nacional em Norbert Elias", in Alain Garrigou e Bernard Lacroix (orgs.), Norbert Elias: a politica e a história, São Paulo, Perspectiva.

CASSIANO, João. (1872), Institutions. Trad. E. Cartier. Paris, Librairie Poussielgue Frères.

COLLIOT-THÉLÈNE, Catherine. (2001), "O conceito de racionalização: de Max Weber a Norbert Elias", in Alain Garrigou e Bernard Lacroix (orgs.), Norbert Elias: a politica e a história, São Paulo, Perspectiva.

DEAN, Mitchell. (1994), Critical and effectives histories: Foucault's methods and historical sociology. Londres, Routledge. (1999), Governmentality: power and rule in modern society. Londres, Sage. . (2007), Governing societies: political perspectives on domestic and international rule. Londres, Open University Press.

DEFERT, Daniel. (2001), "Chronologie", in Michel Foucault, Dits et écrits. Vol. 1: 1954-1975. Paris, Gallimard. 
ELIAS, Norbert. (1994), O processo civilizador. Vol. 2: Formação do Estado e civilização. Trad. Ruy Jungmann. 2 ed. Rio de Janeiro, Zahar.

ESPINOSA, Baruch de. (2003), Tratado teológicopolítico. Trad. intr. e notas Diego P. Aurélio. São Paulo, Martins Fontes. . (2008), Ética. Trad. Tomaz Tadeu. 2 ed. Belo Horizonte, Autêntica.

FONSECA, Márcio Alves da. (2009), "Max Weber, Michel Foucault e a história”, in Margareth Rago e Alfredo Veiga-Neto (orgs.), Para uma vida não-fascista, Belo Horizonte, Autêntica.

FOUCAULT, Michel. (1973), La société punitive. Cours au Collège de France (1972-1973). Paris, Bibliothèque Générale du Collège de France (datilo.).

(1980), Du gouvernement des vivants. Cours au Collège de France, 1979/1980. Paris, Bibliothèque Générale du Collège de France (áudio).

(1981), Subjectivité et vérité. Cours au Collège de France, 1980/1981, Paris, Bibliothèque Générale du Collège de France (áudio).

(1990), "Qu'est-ce que la critique? Critique et Aufklärung”. Bulletin de la Société française de philosophie, 84 (2): 35-63.

. (1993), História da Sexualidade. Vol.

1: A vontade de saber. Trad. Maria T. da C. Albuquerque e J. A. Guilhon Albuquerque. 11 ed. Rio de Janeiro, Graal.

(1999a), História da loucura na Idade

Clássica. Trad. José T. C. Neto. 6 ed. São Paulo, Perspectiva.

(1999b), A ordem do discurso. Aula inaugural no Collège de France, pronunciada em 2 de dezembro de 1970. Trad. Laura F. de A. Sampaio. 5 ed. São Paulo, Loyola.

. (1999c), Em defesa da sociedade. Curso no Collège de France (1975-1976). Trad. Maria Ermantina Galvão. São Paulo, Martins Fontes.

(2001a), Dits et écrits. Vol. 1: 19541975. Paris, Gallimard.

(2001b), Dits et écrits. Vol. 2: 1976-

1988. Paris, Gallimard.

. (2002), A arqueologia do saber. Trad. Luiz Neves. 6 ed. Rio de Janeiro, Forense. (2004a), Sécurité, territoire, population. Cours au Collège de France (1977-1978). Paris, Gallimard/Seuil. (2004b), Naissance de la biopolitique. Cours au Collège de France (1978-1979). Paris, Gallimard/Seuil.

. (2008), Le gouvernement de soi et des autres. Cours au Collège de France (1982-1983). Paris, Gallimard/Seuil.

. (2009), Le courage de la vérité. Le gouvernement de soi et des autres II. Cours au Collège de France (1983-1984). Paris, Gallimard/Seuil. . (2010), Do Governo dos Vivos. Curso no Collège de France, 1979-1980 (excertos). Tradução/transcrição, notas e apresentação de Nildo Avelino. São Paulo/Rio de Janeiro, CCS/ Achiamé.

HALPERIN, David. (1995), Saint Foucault: towards a gay hagiography. Nova York, Oxford University Press.

LANDRY, Jean-Michel. (2007), "Généalogie politique de la psychologie: une lecture du cours de Michel Foucault 'Du gouvernement des vivants' (Collège de France, 1980)”. Raisons Politiques, 25: 31-45.

LASCOUMES, Pierre. (2004), "La gouvernementalité: de la critique de l'État aux technologies du pouvoir". Le Portique, 13/14: 169-190.

LARRAURI, Maite. (1989), "La anarqueología de Michel Foucault". Revista de Occidente, 95: 110-130.

(1999), Anarqueología: teoría de la verdad en Michel Foucault. Valencia, Ediciones Espiteme.

MILLER, Peter \& ROSE, Nicolas. (2008), Governing the present: administering economic, social and personal life. Cambridge, Polity Press.

MISKOLCI, Richard \& SIMÕES, Júlio Assis (orgs.). (2007), "Dossiê: sexualidades disparatadas - Apresentação". Cadernos Pagu, 28: 9-18.

NEGRI, Antonio \& HARDT, Michael. (1994), Labor of Dionysus: a critique of the state-form. Minnesota, University of Minnesota Press.

NIETZSCHE, Friedrich. (1988), Genealogia da moral: um escrito polêmico. Trad. Paulo C. de Souza. 2 ed. São Paulo, Brasiliense. 
(2001), A gaia ciência. Trad. Paulo C. de Souza. São Paulo, Cia. das Letras.

PASQUINO, Pasquale. (1993), "Political theory of war and peace: Foucault and the history of modern political theory". Economy and Society, 22 (1): 77-88.

PROUDHON, Pierre-Joseph. (1947), Las confesiones de un revolucionario: para servir a la historia de la revolución de febrero de 1848. Trad. Diego A. de Santillan. Buenos Aires, Editorial Americalee.

. (1979), Idée générale de la révolution au XIXe siècle. Antony, Fédération Anarchiste. . (1997), O que é a propriedade? . Trad. Marília Caeiro. 3 ed. Lisboa, Editorial Estampa.

RABINOW, Paul \& DREYFUS, Hubert. (1995), Michel Foucault: uma trajetória filosófica. Para além do estruturalismo e da hermenêutica. Trad. Vera P. Carrero. Rio de Janeiro, Forense.

RAGO, Margareth. (2008), "Novos modos de subjetivar: a experiência da organização Mujeres Libres na Revolução Espanhola". Estudos Feministas, 16 (1): 187-206.

SEDGWICK, Eve Kosofsky. (2007), A epistemologia do armário. Trad. Plínio Dentzien, ver. Richard Miskolci e Júlio A. Simões. Cadernos Pagu, 28: 19-54.

SENELLART, Michel. (2004), "Situation des cours", in Michel Foucault, Naissance de la biopolitique. Cours au Collège de France (19781979), Paris, Gallimard/Seuil.

SZAKOLCZAI, Arpád. (1998), Max Weber and Michel Foucault: parallel life-works. Londres, Routledge.

WATSON, Katherine. (2005), "Queer Theory". Group Analysis, 38 (1):67-81.

WEBER, Max. (1997), A ética protestante e o espirito do capitalismo. Trad. M. I. de Q. F. Szmrecsányi e Tomás J. M. K. Szmrecsányi. 12a ed. São Paulo, Pioneira. 


\section{GOVERNAMENTALIDADE E ANARQUEOLOGIA EM MICHEL FOUCAULT}

\section{Nildo Avelino}

Palavras-chave: Poder; Governamentalidade; Anarqueologia; Subjetividade; Verdade.

Este artigo aborda as noçōes foucaultianas de governamentalidade e anarqueologia, enfatizando os impactos que provocaram nas reflexões do "último Foucault". Em um primeiro momento, aborda-se o deslocamento da analítica do poder de Foucault, situando sua importância nos estudos em governamentalidade e sugerindo implicações possíveis que a anarqueologia estabelece com o pensamento de Proudhon. Em seguida, discute-se a maneira pela qual a anarqueologia descreve uma genealogia das formas modernas da obediência ao problematizar a experiência da sexualidade.

\section{GOVERNMENTALITY AND ANARCHAEOLOGY IN MICHEL FOUCAULT}

Nildo Avelino

Keywords: Power; Governmentality; Anarcheology; Subjectivity; Trust.

This article discusses the Foucauldian notions of governmentality and anarchaeology emphasizing the impacts they cause in the reflections of the "final Foucault." At first, it approaches the displacement of the analytical power of Foucault, situating its importance in studies in governmentality and suggesting possible implications that anarchaeology down with the thought of Proudhon. Then it discusses the way anarchaeology describes a genealogy of modern forms of obedience by problematizing the experience of sexuality.

\section{GOUVERNEMENTALITÉ ET ANARCHÉOLOGIE DANS MICHEL FOUCAULT}

\section{Nildo Avelino}

Mots-clés: Pouvoir; Gouvernementalité; Anarchéologie; Subjectivité; Vérité.

Cet article décrit les notions foucaldiennes de gouvernementalité et anarchéologie en mettant l'accent sur leurs impacts dans la réflexion du "dernier Foucault". Initialement, nous abordons le déplacement de l'analytique du pouvoir de Foucault, en situant son importance dans les études de la gouvernementalité et en suggérant des implications possibles que l'anarchéologie établit avec la pensée de Proudhon. Ensuite, nous discutons la façon dont l'anarchéologie décrit une généalogie des formes modernes de l'obéissance à partir de la problématisation de l'expérience de la sexualité. 